\title{
FILSAFAT POLITIK HUKUM PIDANA
}

\author{
Oleh : \\ Ali Imron*
}

\begin{abstract}
Abstrak:
Realitas carut marutnya putusan pengadilan dalam berbagai persoalan bangsa ternyata tidak terlepas dari referensi, pelaku serta tata kelola hukum penguasa atau pemimpin bangsa. Realitas sistem politik pemerintahan yang digunakan oleh bangsa Indonesia ternyata membawa pengaruh besar terhadap berbagai kepentingan kelompok penguasa mulai dari ekskutif, legislatif dan yudikatif dalam mengambil berbagai putusan hukum di pengadilan. Fakta serta realitas tersendiri menyangkut berbagai putusan pidana dalam masalah hukum di Indonesia merupakan sisi hal menarik untuk dikaji serta diteliti secara ilmiah dengan menggunakan pendekatan akademik. Dalam realitas persoalan ini, penulis mencoba menghadirkan pemikiran ilmiah dengan prosedur akademik untuk membaca realitas fenomenologi fakta sejarah serta realitas filsafat politik hukum pidana sebagai kerangka untuk menguji referensi hukum secara normatif-positifis dan berlangsungnya hukum secara empiris sosiologis dalam bingkai hegemoni politik kekuasaan dan sejarah kolonialisme klasik hingga modern.
\end{abstract}

Kata Kunci : Filsafat Politik, Hukum Pidana

\section{Pengertian Filsafat Politik}

Istilah filsafat berasal dari bahasa Yunani yang terdiri dari dua kata yaitu philo dan sophia. Dua kata ini mempunyai arti masing-masing. Philo berarti "cinta" dalam arti lebih luas atau umum yaitu keinginan, kehendak. Sedangkan Sophia

* IAI Tribakti Kediri. 
mempunyai arti "hikmah, kebijaksanaan, dan kebenaran". Jadi, secara etimologis, filsafat dapat diartikan sebagai cinta akan kebijaksanaan. ${ }^{1}$ Politik adalah proses pembentukan dan pembagian kekuasaan dalam masyarakat yang antara lain berwujud pada proses pembuatan keputusan, khususnya dalam Negara. Politik juga sering dikaitkan dengan hal penyelenggaraan pemerintahan dan Negara. Yang menyelenggarakannya bukan rakyat, tetapi pemerintahan yang berkuasa. Hanya saja partisipasi rakyat sangat diharapkan. Tujuannya agar kerja pemerintahan dapat terlaksana dengan baik. Percuma suatu pemerintahan menyelenggarakan Negara tanpa dukungan dari rakyat.

Jadi, pengetian filsafat politik adalah suatu upaya untuk membahas hal-hal yang berkaitan dengan politik secara sistematis, logis, bebas, mendalam, serta menyeluruh. Filsafat Politik berarti pemikiran-pemikiran yang berkaitan tentang politik. Bidang politik merupakan tempat menerapkan ide filsafat. Ada berbagai macam ide-ide filsafat yang ikut mendorong perkembangan politik modern yaitu liberalisme, komunisme, pancasila, dan lain-lain. Filsafat politik adalah refleksi filosofis mengenai masalah-masalah sosial politik yang dapat dibedakan menjadi dua bagian pembahasan yang berkaitan erat, yakni pertama mempersoalkan hakikat, dan kedua mempersoalkan fungsi dan tujuan. Akan tetapi dalam kenyataannya, filsafat politik bukan hanya mempersoalkan hakikat, fungsi dan tujuan Negara, melainkan juga membahas soal keluarga dalam Negara, pendidikan, agama, hak dan kewajiban individual, kekayaan dan harta milik pemerintah dan sebagainya. Filsafat politik berbeda dengan ilmu politik, karena ilmu politik bersifat deskriptif dan bersangkut paut dengan fakta-fakta, sedangkan filsafat politik bersifat normatif dan bersangkut-paut dengan nilai-nilai.

Selanjutnya definisi filsafat politik menurut para ahli

${ }^{1}$ Lebih jauh baca buku Inu Kencana Syafiie, Filsafat Politik; (Jakarta; MandarMaju, 2012) dan buku Tuty Heraty Noerhadi, Aku Dalam Budaya : Telaah Metodologi Filsafat; (Jakarta; Gramedia Pustaka Utama, 2013), Bagus Takwin, Akar - Akar Ideologi Cover; Jogjakarta, Jalasutra, 2012 
adalah

1. Plato, filsafat politik adalah upaya untuk membahas dan menguraikan berbagai segi kehidupan manusia dalam hubungannya dengan Negara. Ia menawarkan konsep pemikiran tentang manusia dan Negara yang baik dan ia juga mempersoalkan cara yang harus ditempuh untuk mewujudkan konsep pemikiran. Bagi Plato, manusia dan Negara memiliki persamaan hakiki. Oleh karena itu, apabila manusia baik Negara pun baik dan apabila manusia buruk Negara pun buruk. Apabila Negara buruk berarti manusianya juga buruk, artinya Negara adalah cerminan mansuia yang menjadi warganya.

2. Machiavelli, filsafat politik adalah ilmu yang menuntut pemikiran dan tindakan yang praktis serta konkrit terutama berhubungan dengan Negara. Baginya, Negara harus menduduki tempat yang utama dalam kehidupan penguasa. Negara harus menjadi kriteria tertinggi bagi akivitas sang penguasa. Negara harus dilihat dalam dirinya tanpa harus mengacu pada realitas apa pun di luar Negara.

3. Agustinus, filsafat politik adalah pemikiran-pemikiran tentang Negara. Menurutnya Negara dibagi 2 (dua) yaitu "Negara Allah" (civitas dei) yang dikenal dengan negra surgawi kerajaan Allah, dan Negara sekuler yang dikenal dengan Negara duniawi (civitas terrena). Kehidupan di dalam Negara Allah diwarnai dengan iman, ketaatan, dan kasih Allah. Sedangkan Negara Sekuler duniawi, menurutnya identik dengan Negara cinta pada diri sendiri atau cinta egois ketidakjujuran, pengmbaran hawa nafsu, keangkuhan, dosa, dan lain-lain. Dengan jelas bahwa filsafat politik Negara Allah Agustinus merupakan penjelmaan Negara ideal Plato.

Selanjutnya secara lebih jauh; Plato dalam bukunya Republika mempersoalkan dan membahas berbagai permasalahan tersebut. Menurut Plato, Negara ideal adalah Negara yang penuh dengan kebajikan dan keadilan. Setiap warganya berfungsi sebagaimana mestinya dalam upaya merealisasikan Negara ideal itu, oleh karenanya maka pendidikan harus diatur oleh Negara. Pendidikan menduduki tempat amat penting dalam filsafat politik Plato. Agar Negara 
ideal itu dapat terwujud nyata, yang patut menjadi raja atau presiden adalah mereka yang mempelajari filsafat. Dengan kata lain raja haruslah seorang filsuf, karena hanya filsuflah yang benar-benar mengenal ide-ide. Selain itu filsuf juga tahu tentang kebijakan, kebaikan dan keadilan, sehingga pemerintahannya tidak akan mengarah pada kejahatan dan ketidakadilan. Menurut Plato, hanya filsuflah yang memiliki pengetahuan yang sesungguhnya, dan karena pengetahuan adalah kekuasaan, maka filsuflah yang layak memerintah.

Sementara Aristoteles berpendapat bahwa Negara adalah persekutuan yang berbentuk polis yang dibentuk demi kebaikan tertinggi bagi manusia. Negara harus mengupayakan dan menjamin kesejahteraan bersama yang sebesar-besarnya karena hanya dalam kesejahteraan umum itulah kesejahteraan individual dapat diperoleh. Menurut dia alangkah baiknya apabila Negara diperintah oleh seorang filsuf-raja yang memiliki pengetahuan sempurna dan amat bijaksana, karena akan menjamin tercapainya kebaikan tertinggi bagi para warganya. Akan tetapi lanjutnya, di dunia ini tidak mungkin dapat ditemukan seorang filsuf-raja yang sempurna, karenanya yang terpenting adalah menyusun hukum dan konstitusi terbaik yang menjadi sumber kekuasaan dan menjadi pedoman pemerintahan bagi para penguasa.

\section{Sejarah Awal Filsafat Politik}

Pada zaman klasik, masih cenderung kepada tokoh sejarah seperti Socrates, Plato dan Aristoteles, kemudian mengenai konsep kekuasaan, kedaulatan Negara dan hakikat hukum. Socrates lahir pada tahun 470 SM, anak dari Sophroniskos seorang tukang batu dan Phainarete seoarang bidan. Sokrates adalah murid dari Arkhelaos, filsuf yang mengganti Anaxagoras di Athena. Ajaran-ajaran Socrates di antarannya berupa metode, etika dan pemikiran tentang politik. Plato tidak membatasi perhatiannya pada persoalan-persoalan etis saja, seperti dilakukan oleh Socrates, melainkan ia mencurahkan minatnya kepada suatu lapangan luas sekali yang mencakup seluruh ilmu pengetahuan.

Pokok pemikiran Aristoteles dari sudut epistimologis menyangkut logika, filsafat pengetahuan, filsafat manusia, 
metafisika dan etika serta filsafat Negara. Aristoteles mencetuskan pemikirannya ketika mulai runtuhnya konsep pemerintahan polis di Athena. Saat itu berlaku konsep mengenai kosmopolitan hellenisme yang diptakarsai oleh raja Alexander de Great. Di dalam bukunya politica, ia menegaskan tentang harus adanya jarak antar ruang pribadi dengan ruang awam dan ruang politik dengan ruang non-politik. Karena pemikiran itulah akhirnya Plato memaparkan inti-inti mengenai konsep warga Negara, konsep hak milik dan konsep komnitas politik. Konsep mengenai hak milik ini kemudian dikembnagkan oleh John Locke.

Selanjutnya filsafat barat abad pertengahan (476-1492 M) bisa dikatakan abad kegelapan, karena pihak gereja membatasi para filosof dalam berpikir, sehingga ilmu pengetahuan terhambat dan tidak bisa berkembang, karena semuanya diatur oleh doktirn-doktrin gereja yang berdasarkan kenyakinan. Apabila terdapat pemikiran-pemikiran yang bertentangan dari keyakinan para gerejawan, maka filosof tersebut dianggap murtad dan akan dihukum berat samapai pada hukuman mati. Secara garis besar filsafat abad pertengahan dapat dibagi menjadi dua periode yaitu: periode Scholastic Islam dan periode Scholastik Kristen. Para Scholastic Islamlah yang pertama mengenalkan filsafat Aristoteles, di antaranya adalah Ibnu Rusyd, ia mengenalkan kepada orang-orang barat yang belum mengenal filsafat Aristoteles. Para ahli pikir Islam (Scholastik Islam) yaitu Al-Kindi, Al-Farabi, Ibnu Sina, AlGazali, Ibnu Rusyd dan lain-lain. Mereka itulah yang memberikan sumbagan sangat besar bagi para filosof eropa yang menganggap bahwa filsafat Aristoteles, Plato, dan Al-Quran adalah benar. Namun dalam kenyataannya bangsa eropa tidak mengakui atas peranan ahli pikir Islam yang mengantarkam kemoderenan bangsa barat. Kemudian yang kedua periode Scholastic Kristen dalam sejarah perkembangannya dapat dibagi menjadi tiga, Yaitu: Masa Scholastik Awal, Masa Scholastik Keemasan, Masa Scholastik Terakhir.

Perkembangan pada era modern/kontemporer, terdapat beberapa filsuf diantaranya yaitu Thomas Hobbes dan John locke. Dasar pemikiran Thomas Hobbes berakar pada empirisme. Menurutya, filsafat adalah ilmu pengetahuan tentang 
akibat-akibat berdasrakan fakta yang bisa diamati. Ia berpendapat bahwa filsafat banyak disusupi oleh gagasan religius dan objek filsafat adalah objek yang bersifat lahiriah dan bergerak dengan cirinya masing-masing. Ia membagi filsafat menjadi empat bidang yaitu filsafat geometri, filsafat fisika, filsafat etika dan filsafat politik. Selanjutnya menurut John locke, kekuadaan Negara adalah terbatas dan tidak mutlak, dan tujuan pemdirian Negara adalah untuk menjamin hak rakyatnya. Maka, peraturan harus mempunyai batasan. John locek dalam bukunya Letters of Toleration menyatakan bahwa jangan menyamakan antara agama dengan Negara, keduanya harus mempunyai pemisah, karena tujuannya berbeda.

\section{Gambaran Filsfat Politik Islam}

Sedikit menengok tentang filsafat politik Islam, bahwasanya Islam merupakan agama universal yang memberikan pedoman setiap aspek kehidupan manusia. Termasuk di dalamnya juga tentang (aspek) kehidupan bernegara. Khusus mengenai kehidupan bernegara, Islam memberikan pedoman amat global, hanya diajarkan prinsipprinsipnya, guna memberi kesempatan bagi interpretasi dan perkembangan masyarakatnya, sesuai dengan kebutuhan hidup yang senantiasa berkembang. Dengan demikian, pemikiranpemikiran dalam bidang kehidupan politik memperoleh ruang gerak yang sangat luas. Berikut ini penulis akan mendiskripsikan garis besar tentang hal tersebut dengan mencoba menggali nuansa-nuansa yang telah termaktub dalam Al-Quran dan Sunnah.

Gambaran filsafat politik Al-Farabi kiranya layak untuk mendapat perhatian kita, lebih sepuluh abad setelah masa hidup sang filosof. Mengapa? Pertama, Al-Farabi adalah filosif politik Islam par excellence. Filosof- filosof muslim yang datang setelahnya terbukti tak banyak beranjak dari apa yang dikembangkan oleh Al-Farabi . Hal ini seperti diakui oleh para filosof-filosof penerusnya. Tokoh-tokoh dari kalagan Islam seperti Ibnu Sina, Al-Ruzi, Al-Thusi maupun dari lingkungan agama lain, seperti Maimonides, dan Ibn Gabirol, mengakui bahwa kualitas filsafat Al-Farabi khususnya di bidang politik, sulit di lampaui. Kedua, banyak peneliti mengenai pemikiran 
Al-Farabi percaya bahwa filsafat Al Farabi ini merupakan suatu upaya yang cukup berhasil untuk mengakomodasikan ajaranajaran Islam ke batang tubuh filsafat klasik, betapapun kontroversialnya. Ketiga, least but not least, meskipun merupakan cerminan abad pertengahan filsafat politik Al Farabi seperti diungkapkan oleh Ibrahim Madkour, seorang ahli filsafat Islam terkemuka, ia mengandung pengertian-pengertian modern, bahkan kontemporer.

Hubungan politik pemerintahan menurut Al-Farabi, bahwa manusia adalah makhluk sosial yang mempunyai kecenderungan alami untuk bermasyarakat lantaran tidak mungkin memenuhi segala kebutuhannya sendiri tanpa melibatkan bantuan dan kerjasama dari orang lain. Adapun tujuan bermasyarakat adalah tidak semata-mata untuk memenuhi kebutuhan pokok hidup, melainkan juga untuk memenuhi kelengkapan hidup yang akan memberikan kebahagiaan, tidak saja material, tetapi juga di akhirat.

Berbeda dengan Al- Mawardi, Untuk menegakkan Negara, dari segi politik, Mawardi berpendapat ada enam sendi dasar yang harus diupayakan yang diantaranya:

1. Agama yang dihayati sebagai pengendali hawa nafsu dan pengawasan melekat atas hati nurani.

2. Penguasa yang berwibawa yang mampu mempersatukan aspirasi yang berbeda sehingga dapat mengantarkan Negara mencapai tujuannya .

3. Keadilan dalam arti luas, keadilan terhadap terhadap bawahan, atasan, dan mereka yang setingkat.

4. Stabilitas keamanan yang terkendali dan merata

5. Kesuburan tanah (lahan) yang berkesinambungan, sehingga tidak tumbuh sebagai aggresor

6. Harapan kelangsungan hidup.

\section{Konsep Pemikiran Filsafat Politik}

Filsafat politik klasik senantiasa bermuara pada etika, yang pada masa itu menduduki tempat paling mulia di antara segala cabang filsafat. Persoalan yang dikemukakan dan pertanyaan yang di ajukan merupakan abstraksi moral yang bersumber dari upaya untuk memberi arti dan makna bagi kehidupan individu dan masyarakat. Dengan demikian ada 
tujuan lebih pasti dan lebih agung yang hendak dicapai, kendati harus melewati perjuangan yang tidak kunjung selesai. Dalam filsafat politik modern, pokok persoalan yang utama adalah masalah individu dan hak-hak miliknya. Itu terlihat jelas lewat tema-tema pembahasan filsafat politik masa kini yang berkisar pada soal kebebasan, otoritas, hak-hak asasi manusia, demokrasi, hak dan kewajiban, keadilan dan lain-lain.

Filosof Yunani kuno Plato merupakan cikal bakal filosof politik Barat dan sekaligus dedengkot pemikiran etika dan metafisika mereka. Pendapat-pendapatnya di bidang ini sudah terbaca luas lebih dari 2300 tahun. Tak pelak lagi Plato berkedudukan bagai bapak moyangnya pemikir Barat. Plato dilahirkan dari kalangan famili Athena kenamaan sekitar tahun 427 SM. Di masa remaja dia berkenalan dengan filosof kesohor Socrates yang jadi guru sekaligus sahabatnya. Tahun 399 SM tatkala Socrates berumur tujuh puluh tahun, Socrates diseret ke pengadilan dengan tuduhan tak berdasar berbuat brengsek dan merusak akhlak angkatan muda Athena. Socrates dikutuk dan dihukum mati. Pelaksanaan hukum mati Socrates yang disebut Plato orang terbijaksana, terjujur, terbaik dari semua manusia yang saya pernah kenal membikin Plato benci kepada pemerintahan demokratis. Tak lama sesudah Socrates meninggal, Plato pergi meninggalkan Athena dan selama sepuluh-dua belas tahun mengembara ke mana kaki membawa.Sekitar tahun 387 SM dia kembali ke Athena, mendirikan perguruan di sana, sebuah akademi yang berjalan lebih dari 900 tahun. Plato menghabiskan sisa umurnya yang empat puluh tahun di Athena, mengajar dan menulis ihwal filsafat. Muridnya yang masyhur, Aristoteles yang jadi murid akademi di umur tujuh belas tahun sedangkan Plato waktu itu sudah menginjak umur enam puluh tahun.

Plato menulis tak kurang dari tiga puluh enam buku, kebanyakan menyangkut masalah politik dan etika selain metafisika dan teologi. Tentu saja mustahil mengikhtisarkan isi semua buku itu hanya dalam beberapa kalimat. Tetapi dengan risiko menyederhanakan pikiran-pikirannya, teringkas pokokpokok gagasan politiknya.yang dipaparkan dalam buku yang kesohor Republik yang mewakili pikiran-pikirannya tentang bentuk masyarakat yang menurutnya ideal. Bentuk terbaik dari 
suatu pemerintahan, usul Plato adalah pemerintahan yang dipegang oleh kaum aristokrat. Yang dimaksud aristokrat di sini bukannya aristokrat yang diukur dari takaran kualitas, yaitu pemerintah yang digerakkan oleh putera terbaik dan terbijak dalam negeri itu. Orang-orang ini mesti dipilih bukan lewat pungutan suara penduduk melainkan lewat proses keputusan bersama. Orang-orang yang sudah jadi anggota penguasa atau disebut guardian harus menambah orang-orang yang sederajat semata-mata atas dasar pertimbangan kualitas.

Plato percaya bahwa bagi semua orang, entah dia lelaki atau perempuan mesti disediakan kesempatan memperlihatkan kebolehannya selaku anggota guardian. Plato merupakan filosof utama yang pertama dan dalam jangka waktu lama nyatanya memang cuma dia yang mengusulkan persamaan kesempatan tanpa memandang jenis kelamin. Untuk membuktikan persamaan pemberian kesempatannya Plato menganjurkan agar pertumbuhan dan pendidikan anak-anak dikelola Negara. Anakanak pertama-tama harus memperoleh latihan fisik yang menyeluruh, tetapi segi musik, matematika dan disiplin ilmu lainnya tidak boleh diabaikan. Pada beberapa tahap ujian ekstensif harus diadakan. Mereka yang kurang maju dialurkan ikut serta terlibat dalam kegiatan ekonomi masyarakat, sedangkan yang maju harus terus melanjutkan dan menerima gemblengan latihan. Penambahan pendidikan ini harus termasuk juga mendalami filosofi yang oleh Plato dimaksud menelaah doktrin bentuk ideal faham metafisikanya.

Keanggotaan guardian tidak dengan sendirinya menarik perhatian masyarakat. Sebab, jadi guardian tidaklah banyak mendapatkan duit. Mereka hanya dibolehkan memiliki harta pribadi dalam jumlah terbatas dan tak boleh punya tanah buat rumah pribadinya. Mereka menerima gaji tertentu dan tetap (itu pun dalam jumlah yang tak seberapa) dan tidak dibolehkan punya emas atau perak. Anggota guardian tidak diperkenankan punya famili yang terpisah tempatnya, mereka harus makan berbareng, punya pasangan bersama. Imbalan buat pentolanpentolan filosof ini bukannya kekayaan melainkan kepuasan dalam hal melayani kepentingan umum. Begitulah ringkasnya sebuah republik yang ideal menurut Plato.

Republik terbaca luas selama berabad-abad. Tetapi harus 
dicatat, sistem politik yang dianjurkan didalamnya belum pernah secara nyata dipraktekkan sebagai model pemerintahan mana pun. Selama masa antara jaman Plato hingga kini umumnya Negara-Negara Eropa menganut sistem kerajaan. Di abad-abad belakangan ini beberapa Negara menganut bentuk pemerintah demokratis. Ada juga yang menganut sistem pemerintahan militer atau di bawah tiran demagog seperti misalnya Hitler dan Mussolini. Tak satu pun pemerintahan-pemerintahan ini punya kemiripan dengan republik ideal Plato. Teori Plato tak pernah jadi anutan partai politik mana pun atau jadi basis gerakan politik seperti halnya terjadi pada ajaran-ajaran Karl Marx.

Memang benar tak satu pun pemerintahan sipil di Eropa disandarkan atas model Plato secara langsung. Namun terdapat persamaan yang mengagumkan antara posisi gereja Katolik di Eropa abad tengah dengan kelas guardian Plato. Gereja Katolik abad pertengahan terdiri dari kaum elite yang mempertahankan diri sendiri agar tidak layu dan tersisihkan, yang anggotanya mendapat latihan-latihan filosofis resmi. Pada prinsipnya semua pria tak peduli dari mana asal-usulnya dapat dipilih masuk kependetaan (meski tidak untuk wanita). Juga pada prinsipnya para pendeta itu tak punya famili dan memang diarahkan semata-mata agar mereka memusatkan perhatian pada kelompok mereka sendiri, bukannya nafsu keagungan disanjung-sanjung.

Peranan partai Komunis di Uni Soviet juga ada yang membandingkannya dengan kelas guardian Plato dalam dia punya republik ideal. Di sini pun kita temukan kelompok elite yang kesemuanya terlatih dengan filosofi resmi. Gagasan Plato juga mempengaruhi struktur pemerintahan Amerika Serikat. Banyak anggota konvensi konstitusi Amerika mengenal dan tak asing dengan gagasan-gagasan politik Plato. Konstitusi Amerika Serikat membuka kemungkinan menggali dan mempengaruhi kehendak rakyat. Dan juga diinginkan sebagai sarana memilih orang-orang yang paling bijak dan paling baik untuk memerintah Negara. Sebagai tambahan teori politiknya, diskusinya di bidang etika dan metafisika telah mempengaruhi banyak filosof yang datang belakangan.

Selanjutnya untuk menggambarkan state of the play dari filsafat politik, ada dua cara:

1. Menjelaskan filsafat politik itu sendiri It is not an essence 
with eternal nature

2. Sebagai tradisi wacana khusus

a. Mendiskusikan ciri-ciri umum

b. Keprihatinan yang telah melatarbelakangi mereka yang mengembangkannya

c. Pergeseran yang menandai garis-garis penting dalam perkembangannya.

3. Hal ini berhubungan dengan dua pertanyaan:

a. Apa pokok masalah (subject-matter) filsafat politik yang semestinya menjadi pegangan kita dalam bekerja?

b. Metode dan pendekatan apa yang mungkin membantu untuk mengembangkan pokok masalahnya, dan bagaimana mereka yang mempelajari filsafat politik memilih metode dan berbagai pendekatan itu?

Kemudian subyek matter filsafat politik adalah memiliki fokus pembahasan masalah yang diantaranya :

a. Menelusuri sejak kapan filsafat politik muncul dan mulai berkembang

b. Membahas tentang hakikat dari organisasi masyarakat yang baik (good) dan tepat (right)

c. Membedakan Filsafat dan filsafat politik.

(1) Filsafat adalah usaha mengejar kebenaran hingga ke akar-akarnya

(2) Filasafat politik merupakan studi tentang penilaian dan kritik moral terhadap proses yang melandasi kehidupan sosial, politik dan ekonomi yang diarahkan pada penciptaan susunan organisasi masyarakat yang baik dan tepat

(3) Studi filsafat politik pada dasarnya merupakan cabang dari filsafat praktis (practical philosophy)

(4) filsafat politik adalah sebagai pengetahuan normative

(5) Membedakan dari ilmu politik dan teori politik

\section{Pemikiran Tentang Hukum Pidana}

Hukum pidana sebagai salah satu bagian independen dari hukum publik merupakan salah satu instrumen hukum yang sangat urgen eksistensinya sejak zaman dahulu. Hukum ini ditilik sangat penting eksistensinya dalam menjamin keamanan 
masyarakat dari ancaman tindak pidana, menjaga stabilitas Negara dan (bahkan) merupakan lembaga moral yang berperan merehabilitasi para pelaku pidana. Hukum ini terus berkembang sesuai dengan tuntutan tindak pidana yang ada di setiap masanya.

Hukum pidana adalah hukum yang mengatur perbuatanperbuatan yang dilarang oleh Undang-Undang dan berakibat diterapkannya hukuman bagi siapa yang melakukannya dan memenuhi unsur-unsur perbuatan yang disebutkan dalam Undang-Undang Pidana. ${ }^{2}$ Seperti contoh perbuatan yang dilarang dalam Kitab Undang-Undang Hukum Pidana, UndangUndang Korupsi, Undang-Undang HAM dan lain sebagainya. Hukum pidana adalah hukum yang mengatur perbuatanperbuatan apa yang dilarang dan memberikan hukuman bagi yang melanggarnya. Sebagian diantara perbuatan yang dilarang dalam hukum pidana adalah pembunuhan, pencurian, penipuan, perampokan, penganiayaan, pemerkosaan, korupsi, dan lainlain.

Hukum pidana dalam arti subyektif disebut juga ius puniendi yaitu sejumlah peraturan yang mengatur hak Negara untuk menghukum seseorang yang melakukan perbuatan yang dilarang. Sementara Dr. Abdullah Mabruk an-Najar dalam bukunya yang berjudul Pengantar Ilmu Hukum mengetengahkan defenisi hukum pidana sebagai kumpulan kaidah-kaidah hukum yang menentukan perbuatan-perbuatan pidana yang dilarang oleh Undang-Undang, hukuman-hukuman bagi yang melakukannya, prosedur yang harus dilalui oleh terdakwa dan pengadilannya, serta hukuman yang ditetapkan atas terdakwa. Hukum pidana adalah bagian daripada keseluruhan hukum yang berlaku di suatu Negara, yang mengadakan dasar-dasar dan aturan-aturan untuk :

1. Menetukan perbuatan perbuatan mana yang tidak boleh dilakukan, yang dilarang, dengan disertai ancaman atau

${ }^{2}$ Baca buku M. Yahya Harahap, Beberapa Tinjauan Mengenai Sistem Peradilan dan Penyelesaian Sengketa, (Bandung; PT. Citra Aditya bakti, 1997) dan R. Soesilo, Kitab Undang-Undang Hukum Pidana (KUHP) Serta Komentar-Komentarnya Lengkap Pasal Demi Pasal, (Bogor; Politeia, 1988) 
sanksi yang berupa pidana tertentu bagi siapa yang melanggar larangan tersebut.

2. Menentukan kapan dan dalam hal hal apa kepada mereka yang telah melanggar larangan larangan itu dapat dikenakan atau dijatuhi pidana sebagaimana yang telah diancamkan.

3. Menentukan dengan cara bagaimana pengenaan pidana itu dapat dilaksanakan apabila ada orang yang disangka telah melanggar larangan tersebut.

Menurut Sudarto, pengertian pidana sendiri ialah hukuman yang diberikan oleh Negara kepada seseorang yang melakukan pelanggaran terhadap ketentuan-ketentuan undangundang (hukum pidana), sengaja agar dirasakan sebagai sanksi. Aturan hukum pidana berlaku bagi setiap orang yang melakukan tindak pidana sesuai asas ruang lingkup berlakunya kitab undang-undang hukum pidana.

Asas hukum pidana diantaranya adalah

1. Asas teritorialitas (teritorialitets beginsel)

2. Asas nasionalitas aktif (actief nationaliteits beginsel)

3. Asas nasionalitas pasif (pasief nationaliteits beginsel)

\section{Sejarah Awal Hukum Pidana}

Sejarah awal mula hukum pidana di dunia, khususnya hukum pidana mati menjadi fenomena sepanjang masa dalam sejarah hukum pidana di dunia. Hukuman pidana mati dimualai sejak adanya Undang-Undang Raja Hamurabi di Babilonia pada abad ke-18 sebelum masehi. Saat itu ada 25 jenis pidana kejahatan yang diancam hukuman mati. Dimulai pada zaman Romawi, dapat dikatakan hukum Romawi yang dituangkan dalam Corpus Iuris Civil berlaku hampir selama seribu tahun atau dalam pertengahan abad ke-6 Masehi. $^{3}$ Dari sinilah kemudian hukum Romawi mengembankan dirinya meliputi wilayah-wilayah yang semakin luas di seluruh Eropa. Gejala ini dinamakan penerimaan (resepsi) hukum Romawi.

Mulai abad pertengahan banyak mahasiswa-mahasiswa

${ }^{3}$ Secara lengkap baca buku Kansil, Pengantar Ilmu Hukum dan Tata Hukum Indonesia, Jilid II, Pengantar Hukum Indonesia (Jakarta; Balai Pustaka, 1993) dan Rozikin Daman, Pancasila Dasar Falsafah Negara, (Jakarta; PT Raja Grafindo Persada, 1995) 
dari Eropa Barat dan Utara belajar di Universitas-universitas di Italia dan Perancis Selatan (dimana Italia merupakan pusat kebudayaan Eropa). Pada era itu yang dipelajari hanya hukum Romawi. Setelah mereka tiba di tanah airnya masing-masing maka hukum romawi akan diterapkan apabila hukumnya sendiri tak dapat menyelesaikan persoalan hukum mereka. Bahkan kadangkala hukumnya sendiri sengaja tidak dipergunakan. Adanya kepercayaan pada hukum alam yang asasi, yang dianggap sebagai suatu hukum yang sempurna dan berlaku bagi setiap waktu (zaman) dan tempat, oleh karena itu mereka yang menerima hukum alam ini dapat melepaskan dirinya dari hukum Romawi yang telah dipelajari di Negara Italia dan Perancis Selatan, maka biasanya mereka menyamakan hukum alam itu hukum Romawi.

Salah satu Negara di Eropa yang meresepsi hukum Romawi adalah Perancis. Hal ini dikarenakan dalam sejarahnya Perancis pernah ditaklukan oleh Caesar, kira-kira 50 tahun sebelum Masehi. Kemudian dalam abad ke-5 sesudah Masehi, timbullah perubahan dimana bangsa Germania memasuki Gallia. Mula-mula bangsa Wetsgota yang menduduki barat daya Gallia. Di bawah pimpinan raja Eurich mereka memperluas daerah mereka sampai Provence dan Auvergene dan sebagaian besar dari Spanyol. Setelah bangsa Westgota kemudian datang bangsa Bourgundi yang menduduki kini dikenal dengan Savoye, dan dari sana memperluas kerajaan mereka kearah selatan.

Kemudian bangsa Salis Franka dibawah Clovis mengalahkan daerah sebelah utara sungai Loire dan dibawah para penggantinya, mengalahkan juga daerah bangsa Bourgundi dan Westgota (kecuali Languedoc) yang dimasukkan ke dalam daerah kerajaan Perancis. Kaisar Napoleon pada tanggal 12 Agustus 1800 membentuk suatu panitia yaitu Portalis, Trochet, Bigot de Preameneu dan Malleville yang ditugaskan untuk membuat rancangan kodifikasi. Sumber bahan kodifikasi adalah hukum Romawi menurut Peradilan Perancis dan menurut tafsiran yang dibuat oleh Potier dan Domat, hukum kebiasaan daerah Paris (Coutame de Paris), peraturan perundangan yang disebut ordonansi dan hukum yang dibuat pada waktu Revolusi Perancis (hukum Intermedier atau hukum sementara waktu). Hasil kodifikasi ini kemudian diumumkan pada tanggal 21 
Maret 1804. Pada tahun 1807 diundangkan menjadi Code Napoleon.

Ketika negeri Perancis dipimpin oleh Napoleon Bonaparte, Perancis telah memberlakukan hukum pidana yang dikenal dengan sebutan code penal, seiring dengan misi Napoleon Bonaparte yang ingin memperluas kekuasaan perancis ke seluruh penjuru eropa maka perancis melakukan ekspansi ke Negara-Negara eropa yang salah satunya Belanda (Nederland). Belanda dapat di taklukkan oleh Napoleon Bonaparte dan secara resmi menjadi Negara jajahan Perancis, Napoleon Bonaparte mengangkat saudaranya sendiri yakni Hendry Napoleon sebagai wakil penguasa Perancis di Belanda, dan semenjak itu pula berlakulah hukum pidana perancis code penal di negeri yang hampir seluruh ketinggian daratannya berada dibawah permukaan laut tersebut.

Setelah penjajah Perancis dapat di usir maka pemerintah kerajaan Belanda menyusun sendiri kitab undang-undang hukum pidananya yang dikenal dengan sebutan Nederlandsch Wetboek van Strafrecht. Di lain pihak yaitu Indonesia (Hindia Belanda) yang kala itu menjadi negeri jajahan Belanda turut berlaku asas hukum, yaitu asas konkordansi dalam hukum pidana. Asas konkordansi adalah asas hukum dimana sedapat mungkin hukum yang berlaku di negeri penjajah dapat diberlakukan di negeri jajahannya atau paling tidak hukum di negeri jajahan menyesuaikan dengan hukum yang berlaku di negeri penjajahnya. Indonesia (Hindia Belanda) masyarakatnya terdiri dari berbagai golongan sehingga tidak bisa serta merta diberlakukan mutlak sesuai hukum pidana yang berlaku di negeri belanda, maka timbul inisiatif untuk mengelompokkan tiap golongan tersebut dan membuat kitab undang- undang hukum pidana yang berlaku bagi tiap-tiap golongan tersebut secara sendiri-sendiri.

Berikut adalah pengelompokannya:

1. Penduduk Eropa : warga Eropa baik dari negeri belanda maupun non belanda namun masih termasuk sebagai bangsa eropa, misalnya : Inggris, Perancis, Rusia dsb. Adapun Bangsa Jepang turut masuk dan disejajarkan dalam kategori penduduk eropa meskipun berasal dari Asia.

2. Penduduk timur asing : warga Arab, dan Cina berikut warga 
keturunannya.

3. Penduduk pribumi : seluruh warga asli pribumi Indonesia dari berbagai suku di tanah air.

Adapun aturan hukum yang diberlakukan adalah:

1. Wetboek van Strafrecht voor Nederlandsch Indie untuk golongan, Penduduk Eropa, ditetapkan dengan Koninklijk Besluit 10 February 1866, yang isinya hanya meliputi kejahatan-kejahatan saja.

2. Wetboek van Strafrecht voor Nederlandsch Indie untuk golongan penduduk Indonesia dan Timur Asing, ditetapkan dengan Ordonantie 6 Mei 1872, isinya pun hanya meliputi kejahatan-kejahatan saja.

3. Algemeene Politie Strafreglement untuk golongan penduduk Eropa, ditetapkan dengan Ordonantie 15 juni 1872, berisi hanya pelanggaran-pelanggaran saja.

4. Algemeene Politie Strafreglement untuk golongan penduduk Indonesia dan Timur Asing, ditetapkan dengan Ordonantie 15 Juni 1872, Isinya pun hanya meliputi Pelanggaranpelanggaran saja.

Pada abad ke XVIII ada dua peristiwa yang menggemparkan, yang mempunyai pengaruh besar terhadap opni publik yaitu mengenai pedagang Jean Calas (1762) di Toulouse dijatuhi hukuman mati. Voltaire telah menggugatnya dan meminta supaya diadakan pemeriksaan revisi. Pemeriksaan revisi terjadi pada tahun 1765 , dimana dinyatakan bahwa Jean Calas tidak bersalah dan putusan yang pertama dibatalkan; tetapi nyawa Jean Calas sudah tidak ada lagi; Peristiwa kedua yang terjadi pada waktu 1764, adalah tulisan Beccaria "Dei delitti $e$ delle pene" yang memprotes pelaksanaan hukuman-hukuman yang diluar peri kemanusiaan dan kejamnya hukuman-hukuman. Kedua peristiwa itu, di samping memberikan anjuran pemakai akal budi pada zaman Renaissance (Aufklarung), sangat banyak pengaruhnya terhadap pembaharuan hukum pidana.

Pada tahun 1791 setelah Revolusi Perancis terbentuk Code Penal yang pertama yang dalam banyak hal dipengaruhi oleh jalan pikirannya Beccaria. Pada tahun 1810 dalam pemerintah Napoleon yang berlaku hingga saat ini, Code Penal tersebut lebih banyak dipengaruhi oleh ajaran dari seorang utilist Inggris yang bernama Bentham. Hukum Pidana ini dalam 
banyak hal masih ditujukan untuk menakut-nakuti, terutama terlihat dari ancaman pidananya. Di Belanda mulai ada gerakan untuk membuat perundang-undangan hukum pidana pada tahun 1795, baru tahun 1809 terwujud : Crimineel Wetboak Voor Het Koningkrijk Holland dalam pemerintahan Lodewijk Napoleon, yang merupakan kodifikasi umum yang pertama yang bersifat Nasional.

Penjajahan Perancis tahun 1811, yang memberlakukan Code Penal Perancis sebagai penggantinya sampai tahun 1886. Pada masa ini C.P. tersebut banyak mengalamai perobahanperobahan terutama mengenai ancaman pidananya yang kejam menjadi diperlunak. Pidana penyiksaan dan pidana cap bakar ditiadakan. Salah satu peristiwa penting yang terjadi ketika itu ialah penghapusan pidana mati (dengan Undang-Undang 17 September 1870 stb. No. 162) dalam Wvs, sedang di WvMS jika terjadi pada waktu damai dan tidak dilakukan kepada musuh. Pada tahun 1881 hukum pidana nasional Belanda terwujud dan yang mulai berlaku pada tahun 1886, yang bernama Wetboek Van Strafrecht sebagai pengganti Code Penal warisan dari Napoleon.

Selanjutnya terkait dengan sejarah hukum pidana di Indonesia. Bahwa bangsa Indonesia mengalami perjalanan sejarah yang sangat panjang hingga sampai dengan saat ini. Beberapa kali periode mengalami masa penjajahan dari bangsa asing. Hal ini secara langsung mempengaruhi hukum yang diberlakukan di Negara ini, khususnya hukum pidana. Hukum pidana sebagai bagian dari hukum publik mempunyai peranan penting dalam tata hukum dan berNegara. Aturan-aturan dalam hukum pidana mengatur agar munculnya sebuah keadaan kosmis yang dinamis. Menciptakan sebuah tata sosial yang damai dan sesuai dengan keinginan masyarakat.

Hukum pidana menurut van hammel adalah semua dasar-dasar dan aturan-aturan yang dianut oleh suatu Negara dalam menyelanggarakan ketertiban hukum yaitu dengan melarang apa yang bertentangan dengan hukum dan mengenakan suatu nestapa kepada yang melanggar peraturan tersebut. Mempelajari sejarah hukum akan mengetahui bagaimana suatu hukum hidup dalam masyarakat pada masa periode tertentu dan pada wilayah tertentu. Sejarah hukum 
punya pegangan penting bagi yuris pemula untuk mengenal budaya dan pranata hukum.

Hukum Eropa Continental merupakan suatu tatanan hukum yang merupakan perpaduan antara hukum Germania dan hukum yang berasala dari hukum Romawi (Romana Germana). Hukum tidak hanya berubah dalam ruang dan letak, melainkan juga dalam lintasan kala dan waktu. Secara umum sejarah hukum pidana di Indonesia dibagi menjadi beberapa periode, yakni:

\section{Masa Kerajaan Nusantara}

Pada masa kerajaan nusantara, banyak kerajaan yang sudah mempunyai perangkat aturan hukum. Aturan tersebut tertuang dalam keputusan para raja ataupun dengan kitab hukum yang dibuat oleh para ahli hukum. Tidak dipungkiri lagi bahwa adagium ubi societas ibi ius sangatlah tepat. Karena dimanapun manusia hidup, selama terdapat komunitas dan kelompok maka akan ada hukum. Hukum pidana yang berlaku dahulu kala berbeda dengan hukum pidana modern. Hukum pada zaman dahulu belum memegang teguh prinsip kodifikasi. Aturan hukum lahir melalui proses interaksi dalam masyarakat tanpa ada campur tangan kerajaan. Hukum pidana adat berkembang sangat pesat dalam masyarakat.

Hukum pidana yang berlaku saat itu belum mengenal unifikasi. Di setiap daerah berlaku aturan hukum pidana yang berbeda-beda. Kerajaan besar macam Sriwijaya sampai dengan kerajaan Demak pun menerapkan aturan hukum pidana. Kitab peraturan seperti Undang-undang raja niscaya, undang-undang mataram, jaya lengkara, kutara Manawa, dan kitab adilullah berlaku dalam masyarakat pada masa itu. Hukum pidana adat juga menjadi perangkat aturan pidana yang dipatuhi dan ditaati oleh masyarakat nusantara.

Hukum pidana pada periode ini banyak dipengaruhi oleh agama dan kepercayaan masyarakat. Agama mempunyai peranan dalam pembentukan hukum pidana di masa itu. Pidana potong tangan yang merupakan penyerapan dari konsep pidana Islam serta konsep pembuktian yang harus lebih dari tiga orang menjadi bukti bahwa ajaran agam Islam mempengaruhi praktik hukum pidana tradisional pada masa itu. 


\section{Masa Penjajahan}

Pada masa periodisasi ini sangatlah panjang, mencapai lebih dari empat abad. Indonesia mengalami penjajahan sejak pertama kali kedatangan bangsa Portugis, Spanyol, kemudian selama tiga setengah abad dibawah kendali Belanda. Indonesia juga pernah mengalami pemerintahan dibawah kerajaan Inggris dan kekaisaran Jepang. Selama beberapa kali pergantian pemegang kekuasaan atas nusantara juga membuat perubahan besar dan signifikan.

Pola pikir hukum barat yang sekuler dan realis menciptakan konsep peraturan hukum baku yang tertulis. Pada masa ini perkembangan pemikiran rasional sedang berkembang dengan sangat pesat. Segala peraturan adat yang tidak tertulis dianggap tidak ada dan digantikan dengan peraturan-peraturan tertulis. Tercatat beberapa peraturan yang dibuat oleh pemerintah kolonial Belanda seperti statuta Batavia (statute van batavia). Berlaku dua peraturan hukum pidana yakni KUHP bagi orang eropa (weetboek voor de europeanen) yang berlaku sejak tahun 1867. Diberlakukan pula KUHP bagi orang non eropa yang berlaku sejak tahun 1873 .

\section{Masa KUHP 1915 - Sekarang}

Selama lebih dari seratus tahun sejak KUHP Belanda diberlakukan, KUHP terhadap dua golongan wargaNegara yang berbeda tetap diberlakukan di Hindia Belanda. Hingga pada akhirnya dibentuklah KUHP yang berlaku bagi semua golongan sejak 1915. KUHP tersebut menjadi sumber hukum pidana sampai dengan saat ini. Pembentukan KUHP nasional ini sebenarnya bukan merupakan aturan hukum yang menjadi karya agung bangsa. Sebab KUHP yang berlaku saat ini merupakan sebuah turunan dari Nederland Strafwetboek (KUHP Belanda). Sudah menjadi konskwensi ketika berlaku asas konkordansi terhadap peraturan perundang-undangan.

KUHP yang berlaku di negeri Belanda sendiri merupakan turunan dari code penal perancis. Code penal menjadi inspirasi pembentukan peraturan pidana di Belanda. Hal ini dikarenakan Belanda berdasarkan perjalanan sejarah merupakan wilayah yang berada dalam kekuasaan kekaisaran perancis. Desakan pembentukan segera KUHP nasional sebagai 
sebuah Negara yang pernah dijajah oleh bangsa asing, hukum yang berlaku di Indonesia secara langsung dipengaruhi oleh aturan-aturan hukum yang berlaku di Negara penjajah tersebut. Negeri Belanda yang merupakan negeri dengan sistem hukum continental menurunkan betuknya melalui asas konkordansi. Peraturan yang berlaku di Negara jajahan harus sama dengan aturan hukum negeri Belanda. Hukum pidana (straffrecht) merupakan salah satu produk hukum yang diwariskan oleh penjajah.

Pada tahun 1965 LPHN (lembaga pembinaan hukum nasional) memulai suatu usaha pembentukan KUHP baru. Pembaharuan hukum pidana Indonesia harus segera dilakukan. Sifat undang-undang yang selalu tertinggal dari realitas social menjadi landasan dasar ide pembaharuan KUHP. KUHP yang masih berlaku hingga saat ini merupakan produk kolonial yang diterapkan di Negara jajahan untukmenciptakan ketaatan. Indonesia yang kini menjadi Negara yang bebas dan merdeka hendaknya menyusun sebuah peraturan pidana baru yang sesuai dengan jiwa bangsa.

\section{Tujuan Hukum Pidana}

Secara konkrit tujuan hukum pidana itu ada dua :

1. Untuk menakut-nakuti setiap orang jangan sampai melakukan perbuatan yang tidak baik.

2. Untuk mendidik orang yang telah pernah melakukan perbuatan tidak baik menjadi baik dan dapat diterima kembali dalam kehidupan lingkunganya. Tujuan hukum pidana ini sebenarnya mengandung makna pencegahan terhadap gejala-gejala sosial yang kurang sehat di samping pengobatan bagi yang sudah terlanjur tidak berbuat baik. Jadi Hukum Pidana, ialah ketentuan-ketentuan yang mengatur dan membatasi tingkah laku manusia dalam meniadakan pelanggaran kepentingan umum. Tetapi kalau di dalam kehidupan ini masih ada manusia yang melakukan perbuatan tidak baik yang kadang-kadang merusak lingkungan hidup manusia lain, sebenarnya sebagai akibat dari moralitas individu itu. Dan untuk mengetahui sebabsebab timbulnya suatu perbuatan yang tidak baik itu(sebagai pelanggaran terhadap ketentuan-ketentuan pidana), maka 
dipelajari oleh kriminologi.

3. Di dalam kriminologi itulah akan diteliti mengapa sampai seseorang melakukan suatu tindakan tertentu yang tidak sesuai dengan kebutuhan hidup sosial. Di samping itu juga ada ilmu lain yang membantu hukum pidana, yaitu ilmu Psikologi. Jadi, kriminologi sebagai salah satu ilmu yang membantu hukum pidana bertugas mempelajari sebab-sebab seseorang melakukan perbuatan pidana, apa motivasinya, bagaimana akibatnya dan tindakan apa yang dapat dilakukan untuk meniadakan perbuatan itu.

Pembaharuan hukum khususnya hukum pidana di Indonesia dilaksanakan melalui dua jalur, yaitu:

1. Pembuatan undang-undang yang maksudnya untuk mengubah, menambah dan melengkapi KUHP yang sekarang berlaku.

2. Menyusun Rancangan Kitab Undang-Undang Hukum Pidana (R-KUHP) yang manfaatnya untuk menggantikan KUHP yang sekarang berlaku yang merupakan warisan kolonial.

Usaha pembaharuan hukum pidana (KUHP) didasarkan pada alasan-alasan baik politik, sosiologis maupun praktis, serta alasan adaptif bahwa KUHP Nasional nanti dapat menyesuaikan diri dengan kecenderungan-kecenderungan Internasional yang diakui oleh masyarakat beradab. Usaha pembaharuan hukum pidana melalui penyusunan R-KUHP sudah dimulai sejak tahun 1958 dengan terbentuknya Lembaga Pembinaan Hukum Nasional (LPHN) yang kemudian diubah menjadi Badan Pembinaan Hukum Nasional (BPHN). Saat ini telah berhasil disusun RUU-KUHP tahun 1999-2000, dimana di samping tetap memandang asas Legalitas sebagai asas yang fundamental bagi Negara Republik Indonesia yang berdasarkan hukum, juga mengakui adanya hukum adat yang memang untuk daerahdaerah tertentu masih hidup dalam masyarakat. Hal ini terlihat dalam Pasal 1 ayat (3) RUU-KUHP tahun 1999/2000, serta Pasal 62 ayat (1) e berupa sanksi pemenuhan kewajiban adat.

Di Pulau Bali sampai saat ini masih terdapat tindak pidana adat yang sebagian besar diselesaikan di luar pengadilan, yaitu melalui Prajuru Desa Adat. Penyelesaian melalui Pengadilan Negeri kepada pelaku hanya dijatuhi pidana seperti 
dalam Pasal 10 KUHP. Hal ini membuat masyarakat adat merasa tidak puas, sehingga kepada pelaku oleh masyarakat adat juga dijatuhi sanksi adat. Dengan demikian ada penjatuhan pidana ganda dalam penyelesaian tindak pidana adat.

Untuk menghindari penjatuhan pidana ganda (pidana menurut KUHP dan sanksi adat), maka terhadap tindak pidana adat yang telah dijatuhi sanksi adat oleh Pimpinan Adat dan yang bersalah telah melaksanakannya, apabila tindak pidana adat tersebut diajukan ke muka pengadilan oleh Jaksa Penuntut Umum, maka tuntutan Jaksa Penuntut Umum tersebut harus dinyatakan tidak diterima.Dengan masih ditaati dan dihormatinya hukum adat untuk daerah-daerah tertentu di Indonesia maka sangat relevan untuk mengangkat ke permukaan hukum pidana adat berserta sanksi adatnya sebagai bahan penyusunan KUHP Nasional.

Pembaharuan KUHP secara parsial/tambal sulam yang pernah dilakukan Indonesia adalah dengan mencabut, menambahkan, atau menyempurnakan pasal-pasal dalam KUHP maupun aturan-aturan hukum pidana di luar KUHP dengan beberapa peraturan perundang-undangan agar sesuai dengan kondisi bangsa dan perkembangan jaman. Pembaharuan hukum pidana materiel dengan model parsial ini telah dilakukan sejak awal Indonesia merdeka dengan disahkannya UU Nomor 1 Tahun 1946 tentang Peraturan Hukum Pidana sebagai akta kelahiran KUHP.

Beberapa peraturan perundang-undangan yang mencabut, menambahkan, atau menyempurnakan pasal-pasal dalam KUHP antara lain sebagai berikut:

1. UU Nomor 1 Tahun 1946 tentang Peraturan Hukum Pidana

Dalam undang-undang ini diatur beberapa hal terkait dengan usaha pembaharuan hukum pidana, antara lain:

a. Mengubah kata-kata NederlandschIndie dalam peraturan hukum pidana menjadi Indonesia.

b. Mengubah nama Wetboek van Strafrecht voor Nederlandsch-Indie menjadi Wetboek van Strafrecht sebagai hukum pidana Indonesia dan bisa disebut KUHP.

c. Perubahan beberapa pasal dalam KUHP agar sesuai dengan kondisi bangsa yang merdeka dan tata 
pemerintahan yang berdaulat.

d. Kriminalisasi tindak pidana pemalisuan uang dan kabar bohong.

2. UU Nomor 20 Tahun 1946 tentang Hukuman Tutupan

Dalam undang-undang ini ditambahkan jenis pidana pokok baru berupa pidana tutupan ke dalam Pasal 10 huruf a KUHP dan Pasal 6 huruf a KUHP Tentara.

3. UU Nomor 8 Tahun 1951 tentang Penangguhan Pemberian Surat Izin kepada Dokter dan Dokter Gigi. Dengan undangundang ini KUHP ditambahkan satu pasal, yaitu Pasal 512a tentang kejahatan praktek dokter tanpa izin.

4. UU Nomor 73 Tahun 1958 tentang Menyatakan Berlakunya UU Nomor 1 Tahun 1946 tentang Peraturan Hukum Pidana untuk Seluruh Wilayah RI dan Mengubah KUH Pidana. Dalam undang-undang ini diatur antara lain sebagai berikut:

1. Pemberlakuan UU Nomor 1 Tahun 1946 untuk seluruh wilayah Republik Indonesia.

2. Penambahan beberapa pasal dalam KUHP, yaitu;

a. Pasal 52 a tentang pemberatan pidana (ditambah 1/3) jika pada saat melakukan kejahatan menggunakan bendera kebangsaan Republik Indonesia.

b. Pasal 142 a tentang kejahatan menodai bendera kebangsaan Negara sahabat.

c. 154 a tentang kejahatan menodai bendera kebangsaan dan lambang Negara Republik Indonesia.

5. UU Nomor 1 Tahun 1960 tentang Perubahan KUHP.

Dengan undang-undang ini ancaman pidana pada Pasal 359, 360, dan 188 diubah, yaitu:

a. Pasal 359 tentang tindak pidana penghilangan nyawa karena kealpaan dipidana lebih berat dari pidana penjara maksimal 1 tahun atau pidana kurungan maksimal 9 bulan menjadi pidana penjara maksimal 5 tahun atau pidana kurungan maksimal 1 tahun.

b. Pasal 360 tentang tindak pidana karena kesalahan menyebabkan luka berat, sehingga menyebabkan orang sakit sementara atau tidak dapat menjalankan profesinya semula dipidana maksimal 9 bulan penjara atau kurungan maksimal 6 bulan atau denda maksimal Rp 
300,-, dipisah menjadi dua ayat yaitu:

(1) Pasal 360 ayat (1) tentang tindak pidana perlukaan berat karena kealpaan dipidana lebih berat menjadi pidana penjara maksimal 5 tahun atau pidana kurungan maksimal 1 tahun.

(2) Pasal 360 ayat (2) tentang tindak pidana perlukaan karena kealpaan sehingga menyebabkan seseorang menjadi sakit sementara atau tidak dapat menjalankan pekerjaan dipidana lebih berat menjadi pidana penjara maksimal 9 bulan atau pidana kurungan maksimal 6 bulan atau pidana denda maksimal Rp. 300,-.

c. Pasal 188 tentang tindak pidana kebakaran, peletusan, atau banjir yang membahayakan umum atau menyebabkan matinya orang lain karena kealpaan dipidana lebih ringan yaitu pidana penjara maksimal 5 tahun atau pidana kurungan maksimal 1tahun atau pidana denda maksimal Rp. 300,-.

6. UU Nomor 16 Prp Tahun 1960 tentang Beberapa Perubahan dalam KUHP. Dengan undang-undang ini, kata "vijf en twintig gulden" dalam Pasal 364, 373, 379, 384, dan 407 ayat (1) diubah menjadi Rp. 250,- (1).

7. UU Nomor 18 Prp Tahun 1960 tentang Perubahan Jumlah Hukuman Denda dalam KUHP dan dalam Ketentuanketentuan Pidana lainnya yang dikeluarkan sebelum tanggal 17 Agustus 1945. Dengan undang-undang ini maka hukuman denda yang ada dalam KUHP maupun dalam ketentuan pidana yang dikeluarkan sebelum 17 Agustus 1945 harus dibaca dalam mata uang rupiah dan dilipatkan lima belas kali.

8. UU Nomor 1 Tahun 1965 tentang Pencegahan Penyalahgunaan dan atau Penodaan Agama.Dengan undangundang ini, Kitab Undang-undang Hukum Pidana ditambahkan pasal baru, yaitu Pasal 156a yang berbunyi:Dipidana dengan pidana penjara selama-lamanya lima tahun barang siapa dengan sengaja di muka umum mengeluarkan perasaan atau melakukan perbuatan:

a. Yang pada pokoknya bersifat permusuhan, penyalahgunaan atau penodaan terhadap suatu agama 
yang dianut di Indonesia

b. Dengan maksud agar supaya orang tidak menganut agama apapun juga, yang bersendikan ke-Tuhanan Yang Maha Esa.

9. UU Nomor 7 Tahun 1974 tentang Penerbitan Perjudian. Dengan undang-undang ini diatur beberapa perubahan beberapa pasal dalam KUHP yang berkaitan dengan tindak pidana perjudian, yaitu:

a. Semua tindak pidana perjudian dianggap sebagai kejahatan.

Dengan ketentuan ini, maka Pasal 542 tentang tindak pidana pelanggaran perjudian yang diatur dalam Buku III tentang Pelanggaran dimasukkan dalam Buku II tentang Kejahatan dan ditempatkan dalam Buku II setelah Pasal 303 dengan sebutan Pasal 303 bis.

b. Memperberat ancaman pidana bagi pelaku bandar perjudian dalam Pasal 303 ayat (1) KUHP dari pidana penjara maksimal 2 tahun 8 bulan atau denda maksimal Rp. 90.000,- menjadi pidana penjara maksimal 10 tahun dan denda maksimal Rp. 25.000.000,-. Di samping pidana dipertinggi jumlahnya ( 2 tahun 8 bulan menjadi 10 tahun dan Rp. 90.000,- menjadi Rp. 25.000.000,-) sanksi pidana juga diubah dari bersifat alternatif penjara atau denda) menjadi bersifat kumulatif (penjara dan denda).

c. Memperberat ancaman pidana dalam Pasal 542 ayat (1) tentang perjudian dalam KUHP dari pidana kurungan maksimal 1 bulan atau denda maksimal Rp. 4.500,penjara maksimal 4 tahun atau denda maksimal $\mathrm{Rp}$. 10.000.000,-. Pasal ini kemudian menjadi Pasal 303 bis ayat (1).

d. Memperberat ancaman pidana dalam Pasal 542 ayat (2) tentang residive perjudian dalam KUHP dari pidana kurungan maksimal 3 bulan atau denda maksimal Rp. 7.500,- menjadi pidana penjara maksimal 6 tahun atau denda maksimal Rp. 15.000.000,-. Pasal ini kemudian menjadi Pasal 303 bis ayat (2).

10. UU Nomor 4 Tahun 1976 tentang Perubahan dan Penambahan Beberapa Pasal dalam KUHP Bertalian dengan 
Perluasan Berlakunya Ketentuan Perundang-undangan Pidana, Kejahatan Penerbangan, dan Kejahatan terhadap Sarana/Prasarana Penerbangan.

a. Memperluas ketentuan berlakunya hukum pidana menurut tempat yang diatur dalam Pasal 3 dan 4 KUHP menjadi berbunyi:Pasal 3 (Ketentuan pidana dalam perundang-undangan Indonesia berlaku bagi setiap orang yang di luar wilayah Indonesia melakukan tindak pidana di dalam kendaraan air atau pesawat udara Indonesia).Pasal 4 (Salah satu kejahatan yang tersebut dalam Pasal 438, 444 sampai dengan Pasal 446 tentang pembajakan laut dan Pasal 447 tentang penyerahan kendaraan air kepada kekuasaan bajak laut dan Pasal 479 huruf $\mathrm{j}$ tentang penguasaan pesawat udara secara melawan hukum, Pasal 479 huruf 1, m, n, o tentang kejahatan yang mengancam keselamatan penerbangan sipil.

b. Menambah Pasal 95a tentang arti pesawat udara Indonesia, 95b tentang arti penerbangan, dan 95c tentang arti dalam dinas.

c. Setelah Bab XXIX KUHP tentang Kejahatan Pelayaran ditambahkan bab baru yaitu Bab XXIX A tentang Kejahatan Penerbangan dan Kejahatan terhadap Sarana/Prasarana Penerbangan. Dalam bab baru ini terdapat 28 pasal baru yaitu Pasal 479a-479r.

11. UU Nomor 27 Tahun 1999 tentang Kejahatan terhadap Keamanan Negara. Dalam undang-undang ini ditambahkan 6 pasal baru tentang kejahatan terhadap keamanan Negara yaitu Pasal 107 a-f.Pelaksanaan pidana mati yang menurut Pasal 11 dilaksanakan di tiap gantungan telah diubah dengan Penetapan Presiden Nomor 2 Tahun 1964 tentang Pelaksanaan Pidana Mati di Pengadilan Militer dan Pengadilan Umum. Eksekusi pidana mati berdasarkan Penetapan Presiden Nomor 2 Tahun 1964 yang kemudian dijadikan UU Nomor 2/PnPs/1964 dilaksanakan dengan cara ditembak.

Di samping adanya beberapa perundang-undangan yang merubah KUHP di atas, terdapat juga beberapa perundangundangan di luar KUHP yang mengatur tentang pidana. Di 
antaranya adalah tindak pidana ekonomi (diatur dalam UU Nomor 7 Drt Tahun 1951 tentang Pengusutan, Penuntutan dan Peradilan Tindak Pidana Ekonomi), tindak pidana korupsi (diatur dalam UU Nomor 3 tahun 1971 kemudian diperbaharui dengan UU Nomor 31 Tahun 1999 dan diperbaharui lagi dengan UU Nomor 20 Tahun 2001), tindak pidana narkotika (diatur dengan UU Nomor 22 Tahun 1997), tindak pidana psikotropika (diatur dalam UU Nomor 5 Tahun 1997), tindak pidana lingkungan hidup (diatur dalam UU Nomor 23 Tahun 1997), tindak pidana pencucian uang (diatur dalam UU Nomor 25 Tahun 2003), tindak pidana terorisme (diatur dengan UU Nomor 15 Tahun 2003), dan lain sebagainya. ${ }^{4}$

\section{Bentuk-bentuk Hukum Pidana}

Pada dasarnya, hukuman atau pidana itu berbagai jenis bentuknya. Akan tetapi, sesuai dengan Bab II (PIDANA), Pasal 10, Kitab Undang-Undang Hukum Pidana (KUHP), bentuk dan jenis pidana dapat digolongkan menjadi 2 (dua) yang diantaranya adalah :

1. Pidana pokok:

a. Pidana mati

b. Pidana penjara

c. Pidana kurungan

d. Pidana denda

e. Pidana tutupan

2. Pidana tambahan:

a. Pencabutan hak-hak tertentu

b. Perampasan barang-barang tertentu

c. Pengumuman putusan hakim.

Sedangkan sifat bagi hukum adalah sifat mengatur dan memaksa. Ia merupakan peraturan-peraturan hidup kemasyarakatan yang dapat memaksa orang supaya mentaati tata-tertib dalam masyarakat serta memberikan sanksi yang tegas (berupa hukuman) terhadap siapa saja yang tidak mematuhinya. Ini harus diadakan bagi sebuah hukum agar kaedah-kaedah hukum itu dapat ditaati, karena tidak semua

\footnotetext{
Baca buku Weboek Van Stafrecht :KitabUndangUndangHukumPidana (KUHP),(Indonesia 1946)
} 
orang hendak mentaati kaedah-kaedah hukum itu.

Hukum pidana terbagi menjadi dua cabang utama, yaitu:

1. Hukum materil ialah cabang hukum pidana yang menentukan perbuatan-perbuatan kriminal yang dilarang oleh Undang-Undang, dan hukuman-hukuman yang ditetapkan bagi yang melakukannya. Cabang yang merupakan bagian dari hukum publik ini mepunyai keterkaitan dengan cabang ilmu hukum pidana lainnya, seperti hukum acara pidana, ilmu kriminologi dan lain sebagainya.

2. Hukum formil (hukum acara pidana) untuk tegaknya hukum materiil diperlukan hukum acara. Hukum acara merupakan ketentuan yang mengatur bagaimana cara agar hukum (materil) itu terwujud atau dapat diterapkan/dilaksanakan kepada subyek yang memenuhi perbuatannya. Tanpa hukum acara maka tidak ada manfaat hukum materiil. Untuk menegakkan ketentuan hukum pidana diperlukan hukum acara pidana, untuk hukum perdata maka ada hukum acara perdata. Hukum acara ini harus dikuasai para praktisi hukum, polisi, jaksa, pengacara, hakim. Mansur Sa'id Isma'il dalam kutipanya mengatakan bahwa defenisi hukum acara pidana adalah kumpulan kaidah-kaidah yang mengatur dakwa pidana, mulai dari prosedur pelaksanaannya sejak waktu terjadinya pidana sampai penetapan hukum atasnya, hak-hak dan kewajiban-kewajiban yang berkaitan dengan hukum yang tumbuh dari prosedur tersebut, baik yang berkaitan dengan dugaan pidana maupun dugaan perdata yang merupakan dakwa turunan dari dakwa pidana, dan juga pelaksanaan peradilannnya. Dari sini, jelas bahwa substansi hukum acara pidana yang berujung menuju pidana meliputi:

1. Dakwa pidana, sejak waktu terjadinya tindak pidana sampai berakhirnya hukum atasnya dengan beragam tingkatannya.

2. Dakwa perdata, yang sering terjadi akibat dari tindak pidana dan yang diangkat sebagai dakwa turunan dari dakwa pidana.

3. Pelaksanaan peradilan, yang meniscayakan campur-tangan pengadilan.

Dan atas dasar inilah, hukum acara pidana, sesuai dengan kepentingan-kepentingan yang merupakan tujuan 
pelaksanaannya, dikategorikan sebagai cabang dari Hukum Publik, karena sifat global sebagian besar dakwa pidana yang diaturnya dan karena terkait dengan kepentingan Negara dalam menjamin efisiensi hukum kriminal. Oleh sebab itu, undangundang hukum acara ditujukan untuk permasalahanpermasalahan yang relatif rumit dan kompleks, karena harus menjamin keselarasan antara hak masyarakat dalam menghukum pelaku pidana, dan hak pelaku pidana tersebut atas jaminan kebebasannya dan nama baiknya, dan jika memungkinkan juga, berikut pembelaan atasnya. Untuk mewujudkan tujuan ini, para ahli telah bersepakat bahwa hukum acara pidana harus benar-benar menjamin kedua belah pihak, pelaku pidana dan korban.

\section{Pelaku Hukum Pidana}

Penegakan Hukum merupakan suatu proses berlangsungnya perwujudan konsep-konsep yang abstrak menjadi kenyataan. Dalam hukum pidana menurut Kadri Husin, penegakan hukum adalah suatu sistem pengendalian kejahatan yang dilakukan oleh lembaga kepolisian, kejaksaan, pengadilan, dan lembaga pemasyarakatan. Menurut Soerjono Soekanto, penegakan hukum adalah kegiatan menyerasikan hubungan nilai-nilai yang terjabarkan di dalam kaedah-kaedah yang mantap dan mengejawantah dan sikap tindak sebagai rangkain penjabaran nilai tahap akhir. Selanjutnya, Soerjono Soekanto menjelaskan bahwa penegakan hukum sebagai suatu proses, pada hakikatnya merupakan penerapan diskresi yang menyangkut membuat keputusan yang tidak secara ketat diatur oleh kaedah-kaedah hukum, tetapi mempunyai unsur penilaian pribadi.

Menurut Soerjono Soekanto faktor yang mempengaruhi penegakan hukum ada lima, yaitu:

1. Hukumnya sendiri, dibatasi pada undang-undang saja

2. Penegak hukum, yakni pihak-pihak yang membentuk maupun menerapkan hukum

3. Sarana atau fasilitas yang mendukung penegakan hukum

4. Masyarakat, yakni lingkungan di mana hukum tersebut berlaku atau diterapkan

5. Kebudayaan, yakni hasil karya, cipta, dan rasa yang 
didasarkan pada karsa manusia di dalam pergaulan hidup

Selanjutnya faktor penghambat dan pendorong di dalam pelaksanaan tugasnya, yaitu:

\section{Faktor Hukum}

Pertentangan antara kepastian hukum dan keadilan disebabkan oleh konsepsi keadilan merupakan suatu rumusan yang bersifat abstrak, sedangkan kepastian hukum merupakan suatu prosedur yang telah ditentukan secara normatif. Penyelenggaraan hukum bukan hanya mencakup law enforcement saja, namun juga peace maintenance, karena penyelenggaraan hukum sesungguhnya merupakan proses penyerasian antara nilai kaidah dan pola perilaku nyata yang bertujuan untuk mencapai kedamaian. Tidak setiap permasalahan sosial hanya dapat diselesaikan oleh hukum yang tertulis, karena tidak mungkin ada peraturan perundangundangan yang dapat mengatur seluruh tingkah laku manusia.Hukum mempunyai unsur-unsur antara lain hukum perundang-undangan, hukum traktat, hukum yuridis, hukum adat, dan hukum ilmuwan atau doktrin.

2. Faktor Penegakan Hukum

Keberhasilan dalam penegakan hukum adalah mentalitas atau kepribadian penegak hukum.Hukum identik dengan tingkah laku nyata petugas atau penegak hukum.Peningkatan kualitas merupakan salah satu kendala yang dialami di berbagai instansi. ${ }^{5}$

3. Faktor Sarana atau Fasilitas Pendukung

Faktor sarana atau fasilitas pendukung mencakup perangkat lunak dan perangkat keras.Perangkat lunak adalah pendidikan dan perangkat keras adalah sarana fisik yang berfungsi sebagai faktor pendukung.Sarana atau fasilitas mempunyai peranan yang sangat penting di dalam penegakan hukum. Tanpa adanya sarana atau fasilitas tersebut, tidak akan mungkin penegak hukum menyerasikan peranan yang

5 Baca buku Soerjono Soekanto, Pengantar Penelitian Hukum (Jakarta; UI Pres, 1986) dan buku Soerjono Soekanto, Pokok-pokok Sosiologi Hukum, (Jakarta; PT Rajagrafindo Persada, 2001) juga buku Teguh Prasetyo dan Abdul Halim Barkatullah, Politik Hukum Pidana, Kajian Kebijakan Kriminalisasi dan Dekriminalisasi, (Yogyakarta; Pustaka Pelajar, 2005) 
seharusnya dengan peranan yang aktual.

4. Faktor Masyarakat

Penegakan hukum berasal dari masyarakat dan bertujuan untuk mencapai kedamaian di dalam masyarakat.Taraf kepatuhan hukum, yaitu kepatuhan hukum yang tinggi, sedang, atau kurang.

5. Faktor Kebudayaan

Fungsi kebudayaan menurut Soerjono Soekanto, mengatur agar manusia dapat mengerti bagaimana seharusnya bertindak, berbuat, dan menentukan sikapnya kalau mereka berhubungan dengan orang lain. Kebudayaan adalah suatu garis pokok tentang perikelakuan yang menetapkan peraturan mengenai apa yang harus dilakukan, dan apa yang dilarang.

6. Kesadaran Hukum

Kesadaran hukum akan terwujud apabila ada indikator pengetahuan hukum, sikap hukum, dan perilaku hukum yang patuh terhadap hukum. Kesadaran hukum yang rendah atau tinggi pada masyarakat mempengaruhi pelaksanaan hukum. Kesadaran hukum merupakan kesadaran atau nilai-nilai yang terdapat di dalam diri manusia tentang hukum yang ada atau tentang hukum yang diharapkan ada..

7. Pelaksanaan Hukum

Hukum diciptakan untuk dilaksanakan.Hukum tidak bisa lagi disebut sebagai hukum, apabila tidak pernah dilaksanakan.Pelaksanaan hukum selalu melibatkan manusia dan tingkah lakunya. Lembaga kepolisian diberi tugas untuk menangani pelanggaran hukum, kejaksaan disusun dengan tujuan untuk mempersiapkan pemeriksaan perkara di depan sidang pengadilan. Menurut Chambliss dan Seidman yang dikutip oleh Satjipto Rahardjo, ada 2 faktor yang menentukan tugas pengadilan, yaitu:

1. Tujuan yang hendak dicapai oleh penyelesaian sengketa itu.

2. Tingkat pelapisan yang terdapat di dalam masyarakat.

Masyarakat yang sederhana cenderung untuk memakai pola penyelesaian berupa perukunan.Sedangkan masyarakat yang tinggi cenderung menggunakan penerapan peraturan atau sanksi.

Penyelesaian konflik atau sengketa menurut Marwan Mas ada 2, yaitu: 
1. Penyelesaian secara litigasi: dilakukan melalui pengadilan

2. Penyelesaian secara nonlitigasi: dilakukan di luar pengadilan yang terbagi atas 4 jenis, yaitu:

a. Perdamaian (settlement), dilakukan sendiri oleh pihakpihak bersengketa.

b. Mediasi (mediation), pra pihak dengan menggunakan jasa pihak ketiga (tidak formal) mediator.

c. Konsiliasi (conciliation), para pihak dengan menggunakan pihak ketiga yang ditunjuk secara formal (ditunjuk oleh MA)

d. Arbitrase (arbitration), para pihak dengan menggunakan pihak ketiga yang ditunjuk secara formal (UU) dan kedudukannya mandiri.

Secara substansial hukum pidana dalam arti obyektif yaitu sejumlah peraturan yang mengandung larangan-larangan atau keharusan-keharusan bagi seseorang dimana terhadap pelanggarnya diancam dengan hukuman.

Hukum pidana mempunyai ruang lingkup yaitu apa yang disebut dengan peristiwa pidana atau delik ataupun tindak pidana. Menurut Simons peristiwa pidana ialah perbuatan salah dan melawan hukum yang diancam pidana dan dilakukan seseorang yang mampu bertanggung jawab. Jadi unsur-unsur peristiwa pidana, yaitu:

1. Sikap tindak atau perikelakuan manusia; melanggar hukum, kecuali bila ada dasar pembenaran yang didasarkan pada kesalahan, kecuali bila ada dasar penghapusan kesalahan.

2. Sikap tindak yang dapat dihukum/dikenai sanksi adalah perilaku manusia. Bila seekor singa membunuh seorang anak maka singa tidak dapat dihukum.

3. Terjadi dalam suatu keadaan, dimana sikap tindak tersebut melanggar hukum, misalnya anak yang bermain bola menyebabkan pecahnya kaca rumah orang.

4. Pelaku harus mengetahui atau sepantasnya mengetahui tindakan tersebut merupakan pelanggaran hukum. Dengan pecahnya kaca jendela rumah orang tersebut tentu diketahui oleh yang melakukannya bahwa akan menimbulkan kerugian orang lain.

5. Tidak ada penyimpangan kejiwaan yang mempengaruhi sikap tindak tersebut.Orang yang memecahkan kaca tersebut 
adalah orang yang sehat dan bukan orang yang cacat mental.

Dilihat dari perumusannya, maka peristiwa pidana/delik dapat dibedakan dalam :

1. Delik formil, tekanan perumusan delik ini ialah sikap tindak atau perikelakuan yang dilarang tanpa merumuskan akibatnya.

2. Delik materiil, tekanan perumusan delik ini adalah akibat dari suatu sikap tindak atau perikelakuan. Misalnya pasal 359 KUHP : Dalam hukum pidana ada suatu adagium yang berbunyi : Nullum delictum nulla poena sine praevia lege poenali, artinya tidak ada suatu perbuatan dapat dihukum tanpa ada peraturan yang mengatur perbuatan tersebut sebelumnya.Ketentuan inilah yang disebut sebagai asas legalitas.

Sistem hukuman yang dicantumkan dalam pasal 10 tentang pidana pokok dan tambahan, menyatakan bahwa hukuman yang dapat dikenakan kepada seseorang pelaku tindak pidana terdiri dari :

1. Hukuman Pokok (hoofd straffen )

a. Hukuman mati

b. Hukuman penjara

c. Hukuman kurungan

2. Hukuman denda

a. Hukuman Tambahan (Bijkomende staffen)

b. Pencabutan beberapa hak tertentu

c. Perampasan barang-barang tertentu

3. Pengumuman putusan hakim. 


\section{DAFTAR PUSTAKA}

Bagus Takwin, Akar - Akar Ideologi Cover; Jogjakarta, Jalasutra, 2012

Bambang Sunggono, Metodologi Penelitian Hukum(Jakarta; Raja Grafindo Perkasa, 2002)

Edi Mulyono, Belajar Hermeunetika; (Jakarta, Diva Press 2012)

Inu Kencana Syafiie, Filsafat Politik; (Jakarta; Mandar Maju, 2012)

Kansil, Pengantar Ilmu Hukum dan Tata Hukum Indonesia, Jilid II, Pengantar Hukum Indonesia (Jakarta; Balai Pustaka, 1993)

M. Yahya Harahap, Beberapa Tinjauan Mengenai Sistem Peradilan dan Penyelesaian Sengketa, (Bandung; PT. Citra Aditya bakti, 1997)

Marci Hamilton, God VsThe Gavel: The Symbol of The Judicial Sistem, Seen in Courtrooms Throughhout The United States, Is Blindfolded Lady Justice; (Cambridge: Cambridge University Press, 2005)

Marco Fabri, The Challenge of Change For Judicial Sistems; (Callifornia, Justice Press, 2000)

Munir Fuadi, Sosiologi Hukum Kontemporer, Interaksi Hukum, Kekuasaan, dan Masyarakat (Bandung; PT Citra Aditya Bakti, 2007)

PranotoIskandar, MemahamiHukum di Indonesia :SebuahKondisiAntaraPolitik, FilsafatdanGlobalisasi; (Bandung; IMR Press, 2010)

R. Soesilo, Kitab Undang-Undang Hukum Pidana (KUHP) Serta Komentar-Komentarnya Lengkap Pasal Demi Pasal, (Bogor; Politeia, 1988) 
Rozikin Daman, Pancasila Dasar Falsafah Negara, (Jakarta; PT Raja Grafindo Persada, 1995)

Sahetapy, Hukum Pidana (Yogyakarta; Liberty, 2004)

Satjipto Rahardjo, Ilmu Hukum (Bandung; PT. Citra Aditya Bakti, 1996)

Soerjono Soekanto, Pengantar Penelitian Hukum (Jakarta; UI Pres, 1986)

Soerjono Soekanto, Pokok-pokok Sosiologi Hukum, (Jakarta; PT Rajagrafindo Persada, 2001)

Sudikno Mertokusumo, Mengenal Hukum, Suatu Pengantar (Yogyakarta; Liberty, 1999)

Teguh Prasetyo dan Abdul Halim Barkatullah, Politik Hukum Pidana, Kajian Kebijakan Kriminalisasi dan Dekriminalisasi, (Yogyakarta; Pustaka Pelajar, 2005)

Tuty Heraty Noerhadi,Aku Dalam Budaya :Telaah Metodologi Filsafat; (Jakarta; Gramedia PustakaUtama, 2013)

Weboek Van Stafrecht :Kitab Undang-Undang Hukum Pidana (KUHP),(Indonesia 1946)

Yudha Bhakti Ardhiwisastra, Hukum Internasional, Bunga Rampai, (Bandung; PT. Alumni, 2003) 